\title{
Cause of Time and Cost Overruns in the Construction Project in Nepal
}

\author{
Bishnu Prasad Khanal*, Sateesh Kumar Ojha \\ Lincoln University College, Mayang Plaza, Taman Mayang Jaya, Petaling Jaya, 47301, Malaysia
}

A R TICLE INFO

Article history:

Received: 14 January, 2020

Accepted: 27 June, 2020

Online: 22 July, 2020

\section{Keywords: \\ Construction \\ Contractor \\ Bid \\ Nepal \\ Time Overrun \\ Cost Overrun}

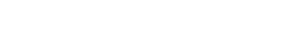

\section{Background}

The development business undertakes a significant job in doing completely created country status. To complete this a country needs to keep its development industry sound by acceptance most recent innovations and dealing with the activities appropriately. Finishing projects on time is a pointer of proficient development industry. Truth be told, a task is considered 'fruitful' on the off chance that it is finished on schedule, inside spending plan and to the predefined quality. Regularly, when the activities are delayed, they are either expanded or quickened and hence, obtain extra expense. To the dislike of proprietors, contractual workers and experts' numerous tasks experience broad postponements and along these lines exceed beginning time and cost measures. The advancement methodology is at risk to various variables and eccentric segments. Conveying a task on time does not happen by trusting that the required fulfillment date will be met. To design and deal with an effective task, the three parameters of time, cost and quality ought to be considered. The customers in the development business are fundamentally worried about quality, time and cost. However, larger part of development activities is secured based on the requirements time and cost. Cost acceleration and time overwhelms are regularly connected with

${ }^{*}$ Corresponding Author: Bishnu Prasad Khanal, Kathmandu, Nepal, bpkhanal123@gmail.com

www.astesj.com

https://dx.doi.org/10.25046/aj050423 poor administration trains. In Nepal the development business is the most remarkable supporter of the financial development. The greatest customer of the development business is government open works projects. These projects are huge for nearby network and must be conveyed on schedule. Any deferral in conveyance won't encourage the full motivation behind the tasks' implementation a work in progress plan. Among all acquirement strategies the Design and Build (D\&B) projects is noteworthy in executing improvement extends in Nepal and different nations.

The undertaking directors and the group need to comprehend the elements causing these postponements and cost overwhelm prompting project disappointments. The quantitative examination of poll review will rundown down the hazard causing factors by positioning. This will help the task administrators and the specialists to make proactive move to such disappointment circumstances. Next area manages time and cost related writing audit pursued by research procedure, exchange and examination by SPSS lastly the ends.

\section{Statement of problems}

There are many works in construction in Nepal. To build the country, there must be different buildings, roads, bridges, etc. with 


\section{B.P. Khanal et al. / Advances in Science, Technology and Engineering Systems Journal Vol. 5, No. 4, 192-195 (2020)}

rapid flights. But here it seems to be slowly delayed for various reasons. Many people have studied in this regard. But no one seems to have thought about reducing it. Therefore, I have prepared this research proposal prepared by studying the main reasons of construction time and cost overrun and looking at how this can be reduced.

Hence urgently needed to study Cause and impact of delay completion of different construction project in Nepal. I have seen this study very important to complete the following tasks.

- Find out the main reason why the construction work is delayed.

- To speed up the construction work quickly, no reason to come.

- Addressing the elements of delay in construction and addressing timely manner.

In addition, there are numerous hazard factors inflicting cost within the Construction Project, afterward, analysts tend to bring this issue into to boot examine with the purpose of characteristic the elements and their positioning of significance. Within the current investigation, scientists have tried to seek out the needs for the underlying evaluated and last add, and completely different reasons for time overcome. In [1] it is discovered four key factors that were the little question affected on cost. These variables incorporate define changes, lack of wisdom, capricious climate condition and also the uncertainty in prices of building materials. it's important to possess a high to the underside understanding of the exceptional problems within the Construction Project. Consequently, the paper expects to offer high to bottom lightweight regarding this reason for project deferral and price overrun in each created and making nations, and framework the attainable proposals for dominant enterprise postponement and price overrun in future activities by dissecting the suitable investigations from numerous nations and Nepal.

Delays on Construction projects are a complete miracle. They are frequently joined by cost and time survives. Development venture postpones have a horrible effect on social occasions (owner, impermanent specialist, and master) to an understanding in regards to a Construction in opposing associations, question, suit, intercession, pay issues, and a general opinion of qualm towards one another [2].

Every project must be in comply with the cost and time estimated and the reasons of delay are to be spotted to assure the project efficiency with respect to time and costs. We can discover an excessive number of research articles about the reason for Construction delay in Nepal. In any case, we can't locate the real reason to postpone top to bottom and we are not the accomplishment to limit the accept Construction works. In Nepal. Henceforth earnestly expected to examine Cause and effect of delay inside and out the fulfillment of various Construction project in Nepal.

\section{Significance of Study}

Development industry has been a bustling industry in the twentieth century. Immense huge numbers of tasks have jumped up, particularly since the Second World War. With the development rate going up continually, a savage rivalry has been set up among the manufacturers. A development project is commonly a progression of exercises that have a particular goal to be finished inside specific determinations and the begin/end dates are all around characterized. The development projects are normally capital serious with a ton of obligation and premium parts and everyone needs to gain benefit on the speculation, as quickly as time permits. This has provoked the flood of quick track projects around the world.

The motivation behind this paper is to examine for all intents and purposes all viewpoints identified with postpone investigation on a development project, trailed by a contextual analysis. Despite the fact that the paper subtle elements for all intents and purposes each perspective related with the defer investigation, spotlight will be on the Lump Sum Contract from the perspective of a contractual worker, as it conveys the greatest hazard for a temporary worker.

As it is the agreement record which subtle elements the approaches if there should be an occurrence of postpone claims, the accompanying segment will examine different kinds of agreements and components for choosing the sort of agreement before formally tolerating it.

\section{Methodology}

\subsection{Data collection}

Information was collected from Construction project. It's time duration on, cost and Management process for Construction works, Procurement process, availability of Labor, materials, government policies, Decision making procedure etc, was studied. This study was carried out based on literature review, questionnaire survey, interview and case study. The research methodology was contained three phases. The first phase was included a literature review, second phase was questionnaire survey, interviews and third phase were carried out by case study. The writing audit was directed through books, meeting procedures, web and universal undertaking the executive's diaries. Questionnaire survey will include 75 respondents made up 10 Consulting firm, 20 Engineers, 15 Contractors, 10 Clients/ Owners, 20 Construction workers/employees. For Contextual investigation two task was chosen. Subsequently, will distinguish reasons for postponement and cost invade in each task independently increase better comprehension for future notice and proactive activities to be embraced in a future undertaking.

\subsection{Literature Review}

The mission to facilitate by providing product and service timely and economically is bound with the constructions projects but they are deviated from estimated costs and time means deviated from, which is often practiced [3]. There is a need of indepth investigation upon the deviations of constructions with respect to time, costs and quality as to minimize its frequent occurrence.

Author in [4] have identified the need of adequate planning to overcome the issues of delays in completion, over-costs and inferior quality of construction projects.

Researches on construction projects, like [1] found the extent of costs exceeded around $30 \%$ in some developing countries. Similarly, [5] did mos detailed studies about these issues and found that $90 \%$ of the projects have cost overrun. 


\section{B.P. Khanal et al. / Advances in Science, Technology and Engineering Systems Journal Vol. 5, No. 4, 192-195 (2020)}

According to [6], behind Cost overwhelms were high transportation cost, change in material detail, and heightening of material cost, visit breakdown of development plants and equipment's and improve. Financial problems are the also major factor causing a delay in construction projects. Technical support is also necessary since the study shows that coordination problems are the second major factor causing delays in construction projects in Malaysia [7]. According to [8], Deferral additionally happens because of outer calculate like change government, guideline and area, inadequate of works and so on.

The mission of facilitating with good and services timely with reasonable costs is affected by the delays. Costly than estimated might have been common in Nepal too. Being developing country and research in this area is needed especially on these issues.

\section{Finding out Causes of cost and Time overrun}

A number of methods applied to study these issues in the country. These methods include survey, observation, literate survey, interview with concerned authorities. These methods together have given insight about the reasons of delay, cost overruns, and quality is that few contractors are assigned many projects in favor. The easy reasons to prove justification for delay and cost overruns are climate change, inflation and natural calamities. All most all the projects have common reasons.

Other issues identified in the study are budget allocation, over ambitious contract duration to complete the project with the contractors merely to communication development efforts, faulty premises at the time of designing and starting the projects, weak monitoring and supervision system, lengthy litigation process to grant project approval, favoritism to the contractors based on the political and financial interests, power influence on the project rather than needs and cost benefits analysis, frequent changes in government and politically favored government officials, who works to please power rather than interest of the country and society. Similarly, studies have indicated some reasons like the interest of cliental group to earn money and take personal benefits, absent of awareness of common people towards what has been being constructed in their areas.

Some other issues are distributing the benefits of the construction to mass political cadres and relatives of political authority, donation of the contractors to run the elections, and win the political battle for which contractors are bound to raise their losses from minimizing the costs and compromising the quality of construction materials and mixtures of materials in a way to violate to standard and eleventh-hour pressure to complete the projects.

Construction delays can be grouped in many ways for their treatments. Some are not so damaging so they can be tolerated, and some are in tolerated to forgive. As the description they are excusable and inexcusable. When delays are there, some can be compensated because no one seems intentionally faulty but by act of god whereas some are caused due to negligence of human beings which cannot be compensated. Whether it is compensable or not also is subject of the terms and conditions of contracts between the contractors and proprietors or clients. Most of the faults and delays occurred due the reasons unspecified in the contracts are compensated. And some are termed as ongoing project which can be improved if any faults found, for instance, schedule can be met with more additional employees, damaging parts of the works can be replaced, and so on. but some have been completed and handed over a in the past for which no other ways remain their rather than to accept it.

Whether a project is excusable or not is subject to reasonableness to excuse or not. For instance, if people involve in the projects make mistakes due to their inefficiency and ignorance then it is not excusable. But many times, it becomes the reason of beyond human ability to repair and maintain then it is called power of god.

The most effective methods of minimizing delay in construction projects are, sufficient financing all through the undertaking, able task administrator, granting offers to the correct originator/contractual worker, complete and appropriate structure at the opportune time, accessibility of assets, clear goal and degree, utilization of experienced subcontractors and providers [9]. The connection between progress nearby and 'solid' supervisory crews underlines the requirement for successful site the executives and oversight by temporary workers and consultants. Labor, at both the specialized and the administrative levels, ought to have their own insight refreshed by nonstop expert improvement plans [10].

In concurrent delays, it should be analyzed just one factors or many to make the project delay and costs. Necessary adjustments can be made through efforts and costs to mitigate the problems reasonably.

According to [11], Helpless site coordination has supposedly been one of the key disappointment boundaries for most Construction ventures. First characteristic under this factor, nonaccessibility of drawing/structure on schedule. Second trait, slow end from proprietor is because of absence of legitimate coordination among proprietor and specialist or proprietor and temporary worker. Third property unworkable time plan given in contract is because of absence of coordination among customer and contractual worker about the pragmatic troubles at the site. Fourth quality helpless site the executives and oversight obviously feature the nonattendance of coordination between different legislative chains of command associated with development industry.

\section{Conclusion}

Problems remain problems if thought efforts are not made to resolve the problems. Reasonably constructions projects are complicated problems inching lots of activities and tools and materials. More parts may call more complications so careful analysis and discussion are necessary to find the resolutions on delays, costs and quality. Construction projects have long impacts, huge investment and lengthy time consuming to complete so mistake also affects these three things. Timely resolving these issues certainly assure the people concerned that they are getting more facilities reasonably. The more expense, more time can be use in other new projects so fast development can be insured.

\section{Reference}

[1] R.K. Shah, "An Exploration of Causes for Delay and Cost Overruns in Construction Projects: Case Study of Australia, Malaysia and Ghana”. 
Journal of Advanced College of Engineering and Management, 2, 2016. https://doi.org/10.3126/jacem.v2i0.16097.

[2] N.A. Ansari, R.M. Swamy, "Methodology to analyse Delay and its impact on construction project". International Research Journal of Engineering and Technology (IRJET), 5(2), 1823-1826, 2018. ISSN:2395-0056

[3] A. Rauzana, "Analysis of Causes of Delay and Time Performance in Construction Projects" IOSR Journal of Mechanical and Civil Engineering, 13, 05, 2016. https://doi.org/10.9790/1684-130503116121

[4] S.A. Hammadi, "Study of Delay Factors in Construction Projects". International Advanced Research Journal in Science, Engineering and Technology, 3(4), 2016. DOI 10.17148/IARJSET.2016.3420

[5] S. Famiyeh, "Major causes of construction time and cost overruns". Business School, Ghana Institute of Management and Public Administration, Accra, Ghana, 2017. https://doi.org/10.1108/JEDT-1120150075

[6] S.S. Mulla, "A Study of Factors Caused for Time \& Cost Overruns in Construction Project \& their Remedial Measures", 5(1), 48-53, 2015 www.ijera.com.

[7] W. Alaghbari, "The significant factors causing delay of building construction projects in Malaysia", 2005. https://doi.org/10.1108/09699980710731308.

[8] L. Mali, A. Warudkar, "Analysis on Causes of Delay in Construction Industry in Pune City". International Journal of Innovative Research in Science, Engineering and Technology, 5(8), 14509-14519, 2016. https://doi.org /10.15680/ijirset.2016.0508028.

[9] T. Pourrostam, A. Ismail, "Study of Methods for Minimizing Construction Delays: Evidences from a Developing Country". Advanced Material Research, 201-203, 2939-2942, 2011. https://doi.org/10.4028/www.scientific.net/amr.201-203.2939.

[10] D.W.M Chan., M.M. Kumaraswamy, "A comparative study of causes of time overruns in Hong Kong construction projects". Internal Journal of $\begin{array}{llll}\text { Project } & \text { Management, } & 1597 .\end{array}$ https://doi.org/10.1016/s02637863(96)00039-7.

[11] H. Doloi, A. Sawhney, K.C. Iyer, S. Rentala, "Analysing factors affecting delays in Indian construction projects". International Journal of Project Management, $30(2012)$ 479-489,

2012. https://doi.org/10.1016/j.ijproman.2011.10.004. 